\title{
守江湾内の八坂川河口沖干潟における カブトガ二孵化幼生の分散機構の解析 DISPERSION MECHANISM OF HATCHLINGS OF HORSESHOE CRAB TACHYPLEUS TRIDENTATUS AT TIDAL FLAT OFF THE YASAKA RIVERMOUTH IN MORIYE BAY
}

\author{
清野聡子 ${ }^{1} \cdot$ 宇多高明 ${ }^{2} \cdot$ 前田耕作 ${ }^{3} \cdot$ 山路和雄 4 \\ Satoquo SEINO, Takaaki UDA, Kosaku MAEDA and Kazuo YAMAJI \\ '正会員 農修 東京大学大学院総合文化研究科広域システム科学科助手（干153-8902 東京都目黒区駒場3-8-1） \\ ${ }^{2}$ 正会員 工博 建設省土木研究所河川部長（T305-0804 茨城県つくば市旭 1 ) \\ 3 東京大学大学院総合文化研究科広域システム科学科研究生 \\ 4パシフィックコンサルタンツ（株）九州本社（†819-0004 福岡県福岡市西区姪浜町33-1 パシコン福岡ビル)
}

\begin{abstract}
Dispersion mechanism of hatchlings of horseshoe crab Tachypleus tridentatus at tidal flat off the Yasaka Rivermouth in Moriye Bay in Oita Prefecture was investigated by field observations of tidal currents and numerical simulation. Hatchlings of horseshoe crab creep out of the sea bottom of the spawning site between two hours before and after the high tide. Field observation of tidal currents on and off the tidal flat and Lagrangian analysis of neutral floats modeled hatchlings show that hatchlings can reach tidal flat, where larva horseshoe crabs live, by the dispersion effect of tidal currents in spite of their low swimming capability. This well explained observed results.
\end{abstract}

Key Words : Horseshoe crab, hatchling, dispersion, tidal currents, Lagrangian analysis

\section{1. まえがき}

「生きている化石」として知られるカブトガニ Tachypleus tridentatus（節足動物剣尾類）は，かつて は瀬戸内海や九州北部の内湾干渴などに広く生息してい たが, 高度成長期に広範に行われた埋立などにより環境 が激変した結果, 現在では絶滅危惧種とされるほどに生 息数が減少している. 水際環境の保全が重要視される現 在,このような絶滅危惧種など, 希少種の生息地保全と, 土木事業との両立策が求められている. 水生生物は その 生活様式や分布が水理により支配される. 特に, 幼生時の 生活史（初期生活史）は，種の存続上重要な段階にある。 幼生は一般に遊泳力が弱いため, 捕食者に襲われても逃 避が困難で, 摂慨力も弱く，この段階での初期減耗が激し い.よって, 保全計画の作成ではこの段階の生存条件を重 視する必要がある. 幼生の分散機構解明への水理的方法 論の援用は, 生物海洋学の創生期から海流や潮流の現地 観測を中心に行われ ", その後数値シミュレーションも 多用されるようになった. しかし, 現在でも生物分散の水 理的解析を行う場合，なお生息環境条件や遊泳力などの 対象生物側の定量的情報が欠如していることが多い. よって, 生物情報の定量化に努めるとともに, 既知の定性 的情報の生物学的妥当性を評価した後に, 外挿を行うこ
とが必要である. 例えば, 中野ら ${ }^{231}$ は吉野川河口干潟に おけるシオマネキの生態と水理の関係について研究した. 筆者らも, カブトガニの生態の解明と生息環境の保全を 目的として, 大分県八坂川河口沖に広がる干潟を対象と して現地観測により同様な観点より研究を行ってきてい

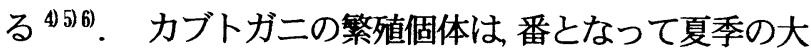
潮期の満潮時前後に, 内湾湾奥部や河川感潮域の砂浜や 砂州に産卵に訪れ，海底面下約 $20 \mathrm{~cm}$ の砂中に産卵する. 卵は約 50 日以上の発生期間を経て, 砂中で躬化に至る。 この射化後の幼生（1 齢幼生）は, 産卵場の砂中から海 底面まではい上がった後，干潟の幼生生息地へと分散し， そこで成長することが知られている. 守江湾内の幼生生 息地は，干潟の空中写真判読から清野ら ${ }^{4}$ が示したよう に, 波浪や河川流の強い作用を受けない安定した干潟に 限定されており, 産卵場と幼生の生息地とは場所的にか なり離れている. しかし, 実際に 1 齢幼生が産卵場から干 潟の生息地に到達可能かどうかについて調べた観測はな い. そこで, 夏季の大潮期の満潮時前後において, すでに カブトガニの産卵場であることが確認 ${ }^{5}$ されている, 首 捻防波堤の産卵場からフロートを投入し, 移動状況を追 跡した. また物理的分散機構を明らかにするために, 干潟 内外での潮流観測や潮流の数値シミュレーションを行っ た. 


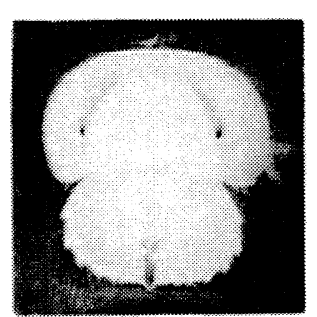

a. 1 嘼幼生

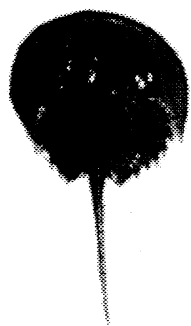

b. 3 嘼幼生

写真-1 カブトガ二の幼生

\section{2. カブトガ二搫化幼生の遊泳行動の特徵}

カブトガニの1齢幼生は, 写真-1aに示すように後体が うちわ状に幅広となっており, 尾剣が小さい. 2齢以上で は後体が相対的に小さくなり, 尾剣が伸長する（写真1b）. 1,2齢間の形態変化より,それに対応した生活形態 の変化が見られる. 躬化直後の 1 齢幼生は産卵場の砂中 やその近傍の水中で発見されるのに対し,2齢以降の幼生 は干潟面を匍匐している状態で発見される.1齢幼生は背 面を下にした遊泳行動を取るが, この体勢は成体におい ても観察される.しかし他段階での遊泳行動は十分わ かっていない. 静水中での 1 齢幼生の遊泳運動は，鰓板を 波打たせて（パドリング），不規則な螺旋状の軌跡を描 いて上昇する不安定な運動である. しかしこの運動は継 続できず, 遊泳をやめて落下するのが頻繁に観察される. また流水中では，流れに向かって泳ぐ様子が観察される ので, 走流性を持つといえる. 以上より, 本研究では, カブ トガニの 1 齢幼生を, 完全な浮遊幼生でも底生生物でも ないpelagic benthosと仮定して考察を行う.

1齢幼生は砂浜，2齢幼生は干潟と生息域が異なること から,その間に幼生が能動的あるいは受動的に移動して 分散することになる. 分散時の行動については, (1)自力で 目的地とする干潟に泳ぎ着く，(2)自力で川底や海底を 這って干潟に至る, (3)産卵場周辺の流れを利用して到達 する,の3通りが考えられる. しかし上述の議論より, パ ターン(3の可能性が高いと想定される.

\section{3. 守江湾のカブトガ二産卵場・生息地および 艀化のタイミング}

守江湾は 図-1 に示すように別府湾北部に位置する面 積 5. $0 \mathrm{~km}^{2}$ の小規模な湾であり,この湾周辺では図示する 場所にカブトガニの産卵場や幼生の生息地が分布する ${ }^{4}$.

カブトガニ躬化幼生の水中への出現タイミングについ ては前田"の研究があり，例えば図-2は，首捻防波堤の産 卵場における幼生の出現状況の観測結果である. 横軸は 満潮時を基淮とした時間差であり. 50個体以上の幼生が

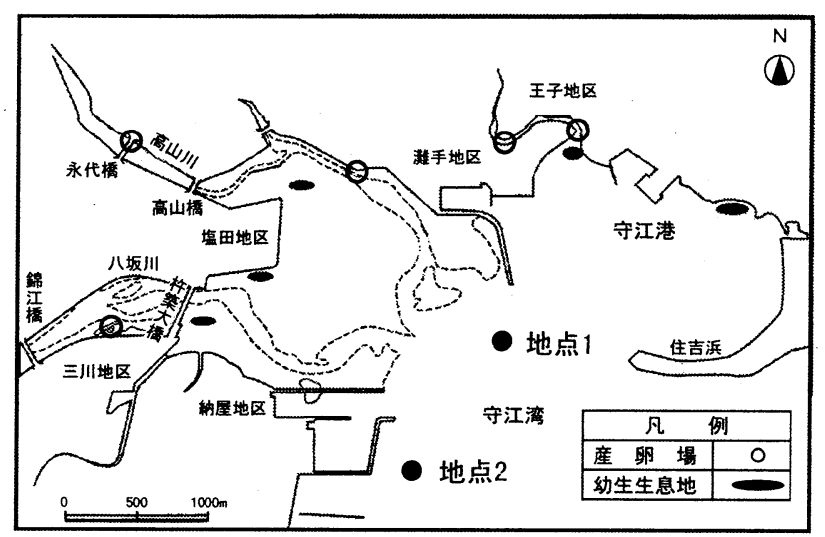

図-1 守江湾におけるカブトガニ産卵場と 幼生の生息地の分布

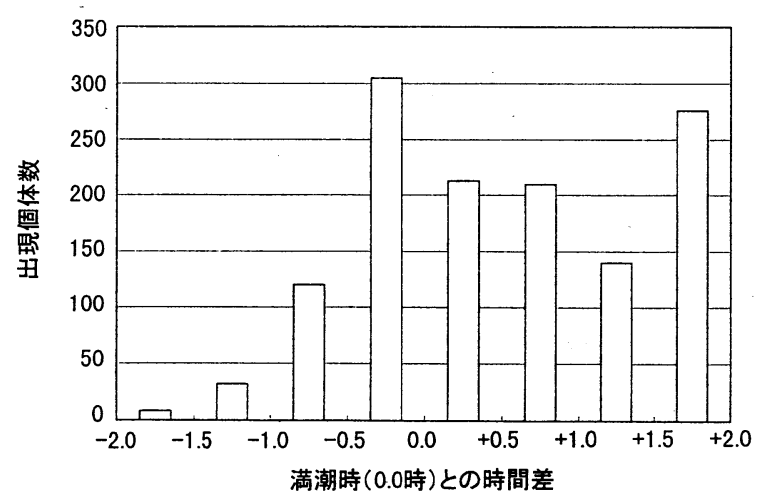

図-2 カブトガニ 1 齢幼生の出現時刻と満潮位の関係

出現した 8 調査日について, 30 分間毎の出現個体数を合 計して求められている. 幼生は満潮前後 2 時間以内に出 現しているが, 出現個体数は満潮前が 465 個体, 満潮後が 842 個体と満潮後のほうが多い.このようにカブトガニ の幼生は満潮前後に出現するために，粰化幼生の移動は 海底から現れた瞬間における産卵場の流れに大きく支配 される。

\section{4. 守江湾の潮位と潮流の観測}

守江湾の杵策大橋直下での, 1997年9月21日～10月22日 の潮位観測デー夕の調和分解によれば, 当海域の潮汐振 幅は $\mathrm{M}_{2}$ 分潮が卓越している. また平均水面はT. P. 0. $15 \mathrm{~m}$ 朔 望平均満・干潮位は $0.92 \mathrm{~m},-0.62 \mathrm{~m}$ にある.

守江湾内の潮流特性を明らかにするため, 干潟上と干 潟沖において観測を行った.干潟上における潮流観測は， 1999年5月 12日 15時〜 5月 13日10時（大潮期）に行った. 調查地点は，図-3に示す塩田地区前面干潟上の2地点（測 点1,2）である. 干潟上に3軸電磁流速計（アレック電子社 製モデルACM16M-7) を設置し, 海底上 $0.2 \mathrm{~m}$ の流れを $0.5 \mathrm{~s}$ 間隔で5分間測定した。 


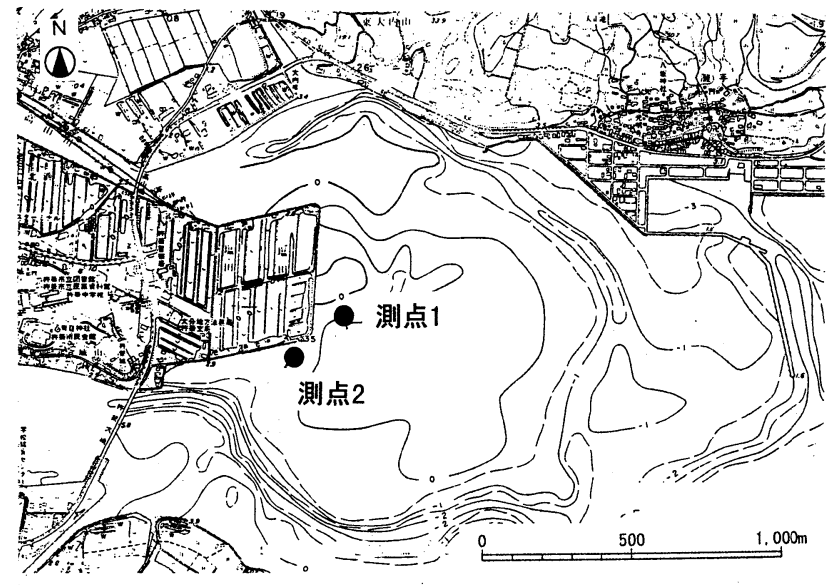

図-3 干潟上における潮流観測地点の位置

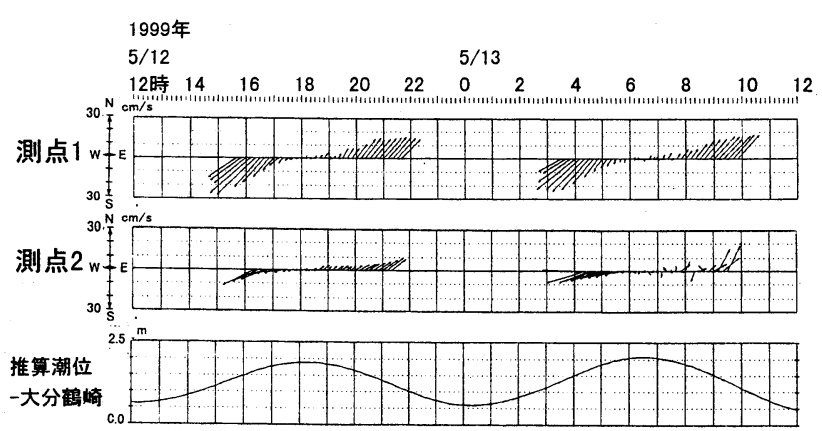

図-4 干潟上における平均流の経時変化

大分港の潮位とともに, 測点1, 2で観測された平均流の 経時変化を図-4に示す. 測点1では，上げ潮時は南西に, 下 げ潮時は北東方向に流れ，澪筋に沿った流れとなってい る. 測点2では，上げ潮時は南西〜西流とほぼ塩田地区南 護岸に沿った流れとなり,下げ潮時は北東流となってい る. 両地点ともに上げ潮時に流速が大きく, 恒流成分が存 在している. そこで, 5月12日の観測記録から恒流成分を 求めると, 測点 1 では $281^{\circ}$ 方向に $1.3 \mathrm{~cm} / \mathrm{s}$, 測点 2 ではN 29 $3^{\circ}$ 方向に2. $6 \mathrm{~cm} / \mathrm{s}$ の恒流となった

干潟沖の潮流観測地点は，図-1に示したように，干潟沖 の八坂川, 高山川および守江港からの下げ潮流が合流す る地点1, およびその神合の納屋港沖の地点2である. 観測 時期は，地点1では1998年11月4日12時〜11月19日12時, 地 点2では1998年11月4日12時〜11月5日13時（大潮期）と した. 図-5には，流向別流速階級別の頻度分布を示す. 地 点1の表層 (海面下 $1 \mathrm{~m}$ ) では，干渴の外縁線とほぼ直交する， 北西および南東方向モードの流れが卓越し,この2方向で 全体の $25.0 \%$ 占める. その平均流速は2. $8 \mathrm{~cm} / \mathrm{s}$ である.

下層 (海底上 $1 \mathrm{~m})$ では, 北北西および南流が卓越し，この2 方向で全体の $27.7 \%$ 占める.

地点2の表層 (海面下 $1 \mathrm{~m}$ ) では，図-1に示したように南 北に延びた納屋港の防波堤の影響を受けて, 北北西また は北流が卓越しており,この2方向で全体の $40.0 \%$ を占め る. 下層 (海底上 $1 \mathrm{~m})$ では北流が圧倒的に卓越しており,

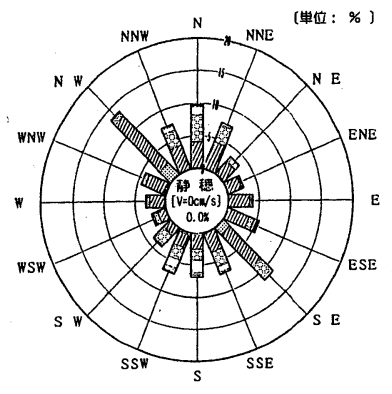

表層（海面下 $1 \mathrm{~m}$ )

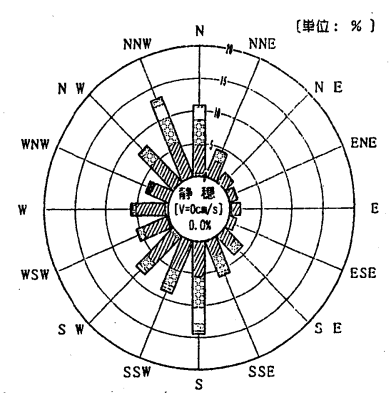

下層（海底上 $1 \mathrm{~m}$ )
地点 1

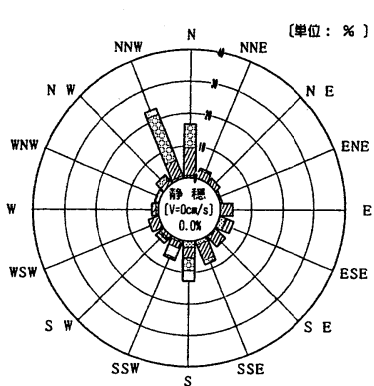

表層（海面下 $1 \mathrm{~m}$ )
下層（海底上 $1 \mathrm{~m}$ )

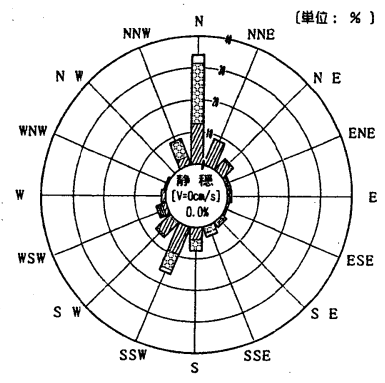

地点 2

図-5 干潟沖における潮流の流向別流速階級別の頻度

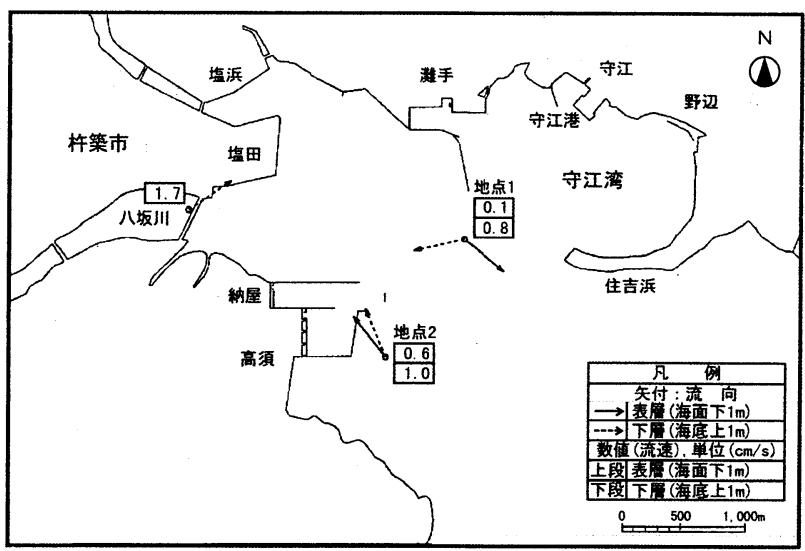

図-6２地点て観測された恒流

この方向で全体の $34.0 \%$ 占める. 流速は弱いものの, 地 点2では上下層とも北向き, すなわち湾内方向への流れが 韩越しいる.

次に, 地点1の15昼夜観測デー夕について最小自乗法に よる調和分解を行い, 10分潮の調和定数および恒流 $\left(\mathrm{V}_{0}\right)$ を 求めた. さらに当海域の流況を把握するために, 潮汐に起 因した潮流の変化として平均大潮期の流況と潮流以外の 成分としての恒流（平均流）について検討した. 恒流を 図-6に示す．流速は微弱であるが, 表層（海面下 $1 \mathrm{~m}$ ）で は時計回りの環流が生じている. 一方下層（海底上 $1 \mathrm{~m}$ ) では，西流傾向を示し湾内に向かう流れとなっている. 
表-1 潮流計算条件一覧

\begin{tabular}{|c|c|}
\hline 計算領域 & $8400 \mathrm{~m} \times 4500 \mathrm{~m}$ \\
\hline 水 & 1996年の深浅测量図による \\
\hline メッシュ長 & $100 \mathrm{~m} \times 100 \mathrm{~m}$ (84×45メッシュ) \\
\hline 層分割 & 第1層＼cjkstart海面～T. P. -2.0m \\
\hline & 第2層 T.P. $-2.0 \mathrm{~m} \sim-5.0 \mathrm{~m}$ \\
\hline & 第3層 T.P. $-5.0 \mathrm{~m}$ 以深 \\
\hline 多仏不叭 & $6 \mathrm{~s}$ \\
\hline 全計算時間 & 48時間（满潮からスタートして4潮汐分） \\
\hline 基準水位 & +0.15m (N. S. L.) \\
\hline 水平渦動 & $0.4 \times 10^{4} \mathrm{~cm}^{2} / \mathrm{s}$ \\
\hline 粘性係数 & \\
\hline 表面摩擦保数 & 0.0013 \\
\hline 層間摩擦保数 & 0.0020 \\
\hline 海底摩擦保数 & マニングの粗度係数を0.03とし, \\
\hline & Chezy式により水媣の関数として与える. \\
\hline 水平㹡散係数 & $0.4 \times 10^{4} \mathrm{~cm}^{2} / \mathrm{s}$ \\
\hline 鉿直㹡散俰数 & $1 \mathrm{~cm}^{2} / \mathrm{s}$ : エスチャリー（河口域）の一般値 \\
\hline 干出水位 & $0.05 \mathrm{~m}$ \\
\hline 水位境界 & $\begin{array}{l}\text { 東端・南端境界上で振幅0.77m [平均大潮期の潮位振幅値] } \\
\text { 周期 } 12.00 \mathrm{hr}\end{array}$ \\
\hline 河川境界 & 八坂川で1. $12 \mathrm{~m}^{3} / \mathrm{s}$ \\
\hline & 高山川で0. 32m³/sの流入条件 \\
\hline 塩分丧度 & 初期值 - 境界值は33.0 \\
\hline
\end{tabular}

\section{5. 守江湾の潮流解析}

守江湾内の潮流の平面的な挙動を把握するために, 現 地潮流調査に基づいた潮流計算を行った. 守江湾には広 大な干潟が広がっているために, 干潟の干出を考慮でき るモデルを採用した. 本解析で用いる計算モデルは藤原 ら ${ }^{8)}$ のモデルである. このモデルでは, 密度変化の原因と なる温度・塩分濃度の変化がそれほど大きくなく, かつ 水の非圧縮性を仮定し, 圧力による変化を無視して, 連続 の式と運動方程式を差分化して解くものである. また熱 仪支と塩素量についてはそオどオ移流厸散っ程式を用い る. さらに, 状態方程式については, 塩素量と水温から密 度を計算するためのKnudsenの式を用いる.

一般的な海域において適用される3次元モデルのうち, 鈶直流が計算でき, 成層期, 非成層期の区別なしに適用で きるマルチレベルモデルを用いた.このモデルは海域を 直方体のセルに分割し，その中で基礎方程式を積分し, 解 を求めるものである. また, 本計算では, 各計算点表層の 干出・没水の判定によって移動境界処理を行った.

海域にある計算点表層の層厚（水位一水深）が一定值 （0.05mと設定）より小さくなった場合, その点は干上 がったとみなし, 隣接点との全ての境界を不透過に, 境界 上での流速をゼロとした. また, ある海域の水位が, 隣接 する陸地の高さより一定以上高くなつた場合, その陸地 に海水が流入し水没するとみなしたこの時, 海一陸の境 界を透過境界とし, その陸地に海域の水位・水質を外扦 した. 同時刻に一つの陸地へ複数の海域からの流入が生 じた場合には，水位・水質は各々の平均値とした これら の処理を毎時間・全計算点（表層）で行った.こうして 汀線を潮位によって変化させ, それを境界条件として潮 流計算を行った 潮流計算の計算条件を表-1に示す.

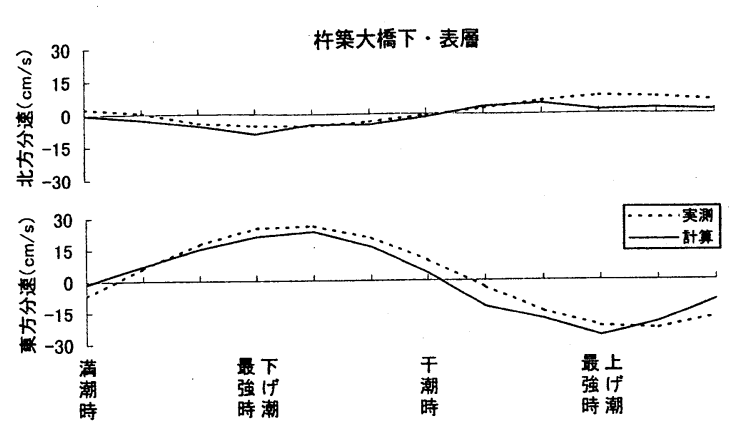

図-7 杵築大橋直下での潮流計算結果と 現地調査結果との比較

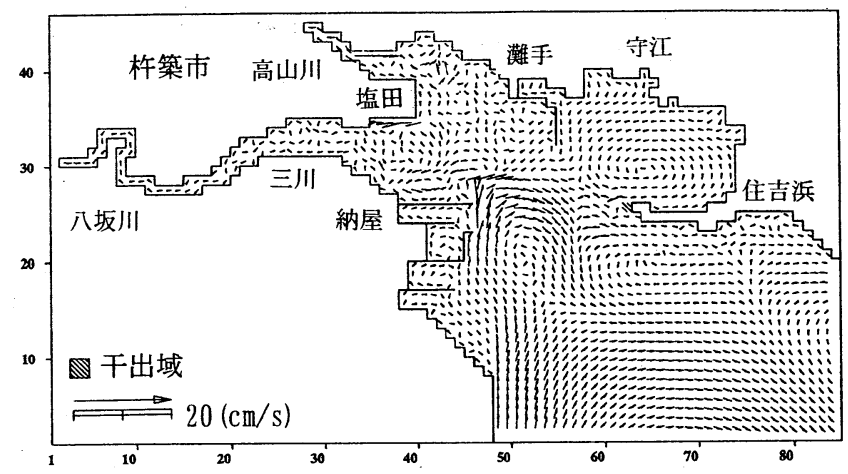

図-8＼cjkstart計算された平均流の分布 (表層)

\section{6. 潮流の実測值との比較}

現地観測時の表層・下層を計算上の第 1,2 層とし, 現地

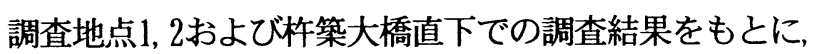
現地で得られた平均大潮期の 1 時間おきの流向・流速と 平均大潮期の潮流計算值を比䡈し, 流れて現況再現性を 調べた. 現況再現性は, 流向・流速から求められるべクト ル成分を北方・東方分速に分け，その変化状況を比較す ることにより判断できる. 一例として杵築大橋直下での 潮流観测結果の調和分解後, 計算された平均大潮期の流 速と計算値の時間的変化は，図-7に示す通りである. 流況 は概ね一致しており, 現況再現性が得られている.

各時刻の潮流を計算した後,それらの残差流成分とし て求めた表層の平均流の分布は図-8に示す通りである. 平均流は計算条件から判断すると, 密度流と潮夘残差流 の合成流と考えられる. 河川域は河川流の影響を受け, 河 川を下る流れとなっているが, 干潟周辺の流れは複雑で あり, 八坂川河口部や高山川河口部では所々に反時計回 りの環流を生じている. とくに特徴的な流れとしては, 高 山川から八坂川へ向かう流れで, その一部は塩田南側護 岸に沿って八坂川を遡上し, 杵築大橋下流域で向きを転 じ, 八坂川へと流入している.八坂川を下ってきた流れは, 湾外へ流出する流れ，守江港内へ向かう流れ，および高山 川を遡上する3つの流れに別れ，干潟部では地形性の反時 計回りの環流を形成している. 一方, 納屋港と住吉浜砂嘴 の間の海域では, 時計回りの環流が形成されている.この 環流は図-6に示した実測値とほぼ対応を示している. 


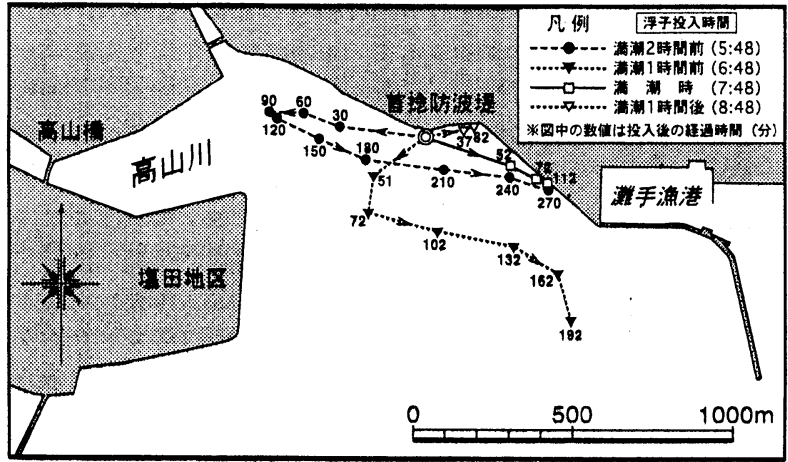

図-9＼cjkstart首捻防波堤周辺でのフロート追跡結果

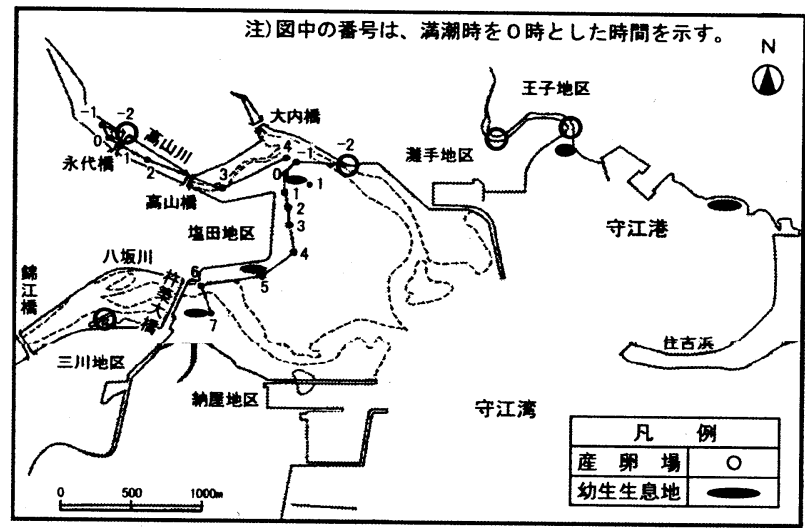

図-10a カブトガニ粰化幼生の推定分散しレート(満潮前 2 時間)

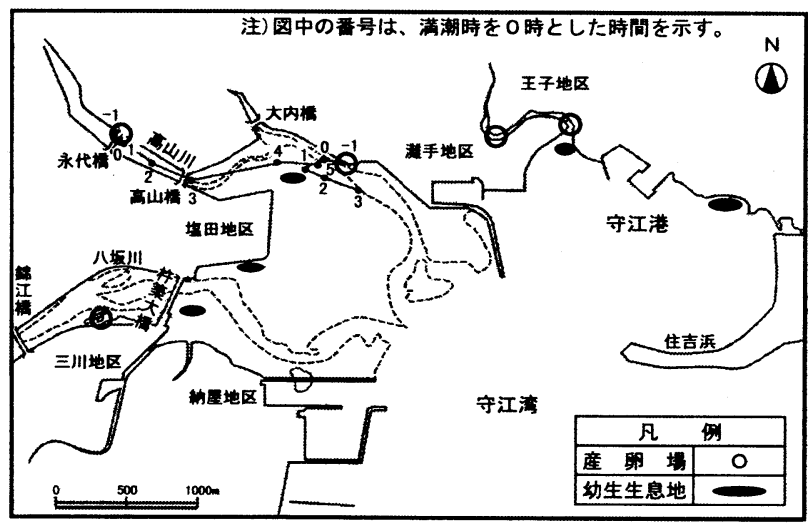

図-10b カブトガニ稃化幼生の推定分散ルレート (满潮前 1 時間)

\section{7. カブトガ二餒化幼生の分散解析}

まず, 射化幼生の分散解析の検証デー夕を得るために, 首捻防波堤周辺で鍾付きビニールボールを用いたフロー ト観測を1997年9月1日に実施した. 図-9にはフロート追 跡結果を示す. 満潮2時間前に投入されたフロートは高山 川沖の流路を遡って2時間後には塩田地区の北側へ到達 したあと, 下流方向へと流れの向きが変化した. そしてこ の間, 塩田地区沖の干潟上を流れている. 満潮1時間前に 投入されたフロートは反時計回りに回転しながら下流方 向へ流れた. しかし, 満潮時以降に投入されたフロートは 下流方向に流れており, 塩田地区沖には到達していない．

カブトガニの 1 齢幼生を, 完全な浮遊幼生でも底生生 物でもないpelagic benthosと仮定すると, 粰化幼生の運

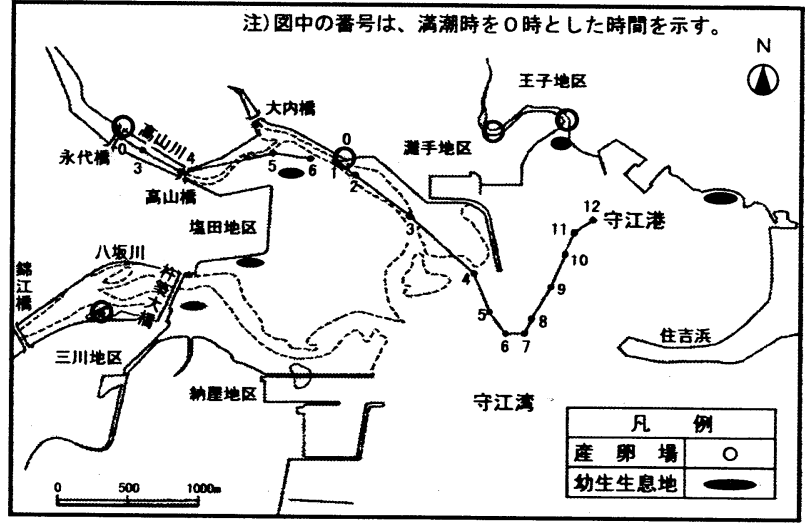

図-10c カブトガ二粰化幼生の推定分散ルレート (満潮時)

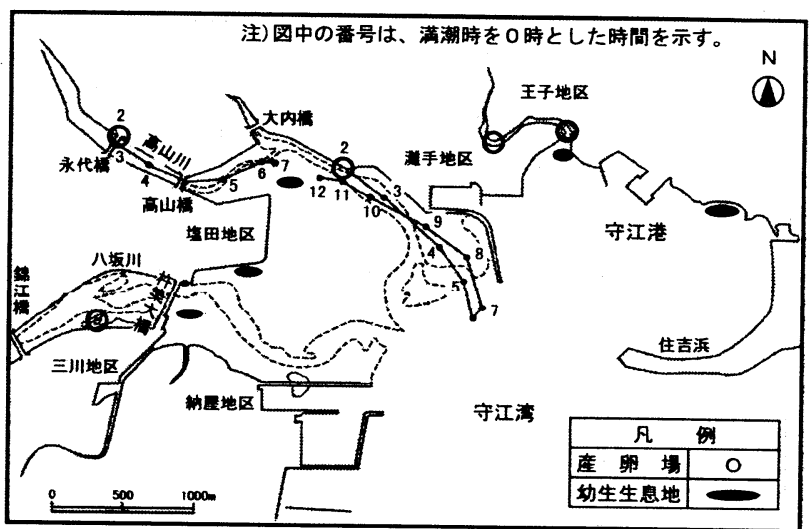

図-10d カブトガ二粰化幼生の推定分散レレト (満潮後 2 時間)

動は水粒子の運動とほぼ同様になると考えられる. その 場合，中野ら ${ }^{23)}$ と同様な考えにより, 潮流シミュレー ション結果をもとに水粒子をラグランジュ的に追跡すれ ば, 産卵場からの幼生の分散機構の把握が可能になる. 図 -10a, b, c, dには, カブトガニ生息地分布とカブトガニ躬 化幼生の推定分散ルートを示す.なお, 時間の基準は満潮 時とする.

\section{（1）满潮2時間前に出現した場合（図-10a）}

首捻防波堤の産卵場から出現した粰化幼生は, 満潮 1 時間前から満潮時に, この海域周辺で形成される反時計 回りの環流に乗り, 塩田地区沖の幼生生息地に到達した. この状況は観測結果とほぼ一致する.さらに, 1時間後に 環流から分岐した流れに乗った幼生は，塩田地区東側護 岸に沿って南下し, 5時間後には塩田地区南側護岸周辺の 幼生生息地に達した. その後, 強い西流に乗り, 八坂川を 遡り7時間後には八坂川右岸の生息地に達した.一方, 永 代橋の産卵場から出現した粰化幼生は，上げ潮流に乗っ てしばらく高山川を遡上した後, 下げ潮となって満潮時 から4時間後には塩田地区神の幼生生息地のごく近傍に 到達した。

（2）满潮 1 時間前に出現した場合（図-10b）

首捻防波堤の産卵場から出現した粰化幼生は, 上げ潮 流に乗り, 満潮1時間後には塩田地区沖の幼生生息地の近 傍に達した. しかし, 满潮1時間後は下げ潮流に転流して いるため, 下流方向へ急速に流される.この結果も観測結 
果をよく説明している. 一方, 永代橋の産卵場から出現し た躬化幼生は，下げ潮流に乗って下流に運ばれ，4時間後 には塩田地区沖の幼生生息地の近傍に達した。

（3）満潮時に出現した場合（図-10c）

首捻防波堤の産卵場から出現した粰化幼生は, 出現直 後は上げ潮に乗って高山川河口へと遡上したが, 満潮1時 間後に転流する下け潮流に乗り高山川沖の澪筋を流下し， 灘手漁港の防波堤を大きく迁回して流れ，12時間後には 守江港沖に達した. 到達地点は，江頭川河口沖の幼生生息 地に近接してはいるが, 到達地点の水深は約 $3.5 \mathrm{~m}$ と大き く,かつ守江港にも近いため, 幼生が最終的に生息地に到 達可能かどうか疑問である. 永代橋の産卵場から出現し た幼生は，下げ潮流に乗り 5,6 時間後には塩田地区沖の幼 生生息地の近傍に達した. このことから, 永代橋の産卵場 から出現した幼生は塩田地区沖の幼生生息地に到達可能 と言えるが, 首捻防波堤から出現した幼生は到達が困難 と考えられる.

\section{（4）満潮2時間後に出現した場合（図-10d）}

首捻防波堤の産卵場から出現した粰化幼生は直ちに 下げ潮流に乗り, 高山川沖の澪筋を流下して 7 時間後に は灘手漁港の防波堤先端沖に達した. そこから上げ潮流 に乗って遡上し, 12 時間後には幼生生息地近傍まで到達 した. しかしこれだけ長い時間幼生が浮遊状態を保てる かどうかは疑問である. 永代橋の産卵場から出現した幼 生は, 下け潮流に乗って下流に輸送され、7時間後に, 高山 川河口の幼生生息地の近傍に達した. この場合も, 首捻防 波堤から出現した幼生は塩田地区沖の幼生生息地に到達 しにくく, 永代橋直下の産卵場から出現した幼生のほう が塩田地区沖の幼生生息地に到達しやすいことが分かる.

以上のようにフロート锰測と, 潮流シミュレーション に基づく水粒子のラグランジュ的追跡によれば, 少なく とも首捻防波堤と永代橋から出現したカブトガ二幼生は， 海底面からの出現時間によっては比較的短時間で干潟の 幼生生息地に到達可能なことが結論される.

\section{8. まとめ}

カブトガニ生息地の保全のためには，対象生物の生活 史を考える必要がある. その種が回遊や移動を行う場合 には，生活史の完遂を支える物理的条件，特に外的要因か ら大きな影響を受け易い躬化幼生の分散については, 流 れの条件が満たされる必要がある. したがってカブトガ 二の保護においては，単にミク口的に見た産卵場の保全 だけではなく, 人工構造物の構策などによる, 潮流場の変 化についても十分な注意を払う必要がある. とくに守江 湾の塩田地区のように, 干拓地の護岸が直線的に延ばさ れたり,あるいは防波堤などの施設が建設されると, その 背後に反流域が形成されたり, あるいは構造物に沿った 流れが生じ，それによって従来カブトガニの稃化幼生が 到達可能であった場所に到達が不可能になる事態も想定
される. また, カブトガニの産卵場と幼生生息地との関係 に関して, 潮流条件によっては産卵場に最も近接する生 息地のみが幼生生息地とは限らないことも明らかになっ た.これらのことは, 湾内の干潟全体を視野に入れたカブ トガニ生息地の保全を進めるべきこと, そしてカブトガ 二の粰化幼生の分散については, サンプリング調查や潮 流観測だけではなく, 本研究で明らかにした数值シミュ レーションが有効な手段となることが明らかである. 今 後, 各種地形改変が希少種の生息環境に及ぼす影響の評 価や，あるいは影響のより少ない案の作成において, 本研 究で示した手法の有効利用が期待される.

謝辞 : 守江湾では, 下水道の終末処理場の施設が湾岸に 建設されているが, 干潟に及ぼす排水の影響検討とその 軽減策について, 九州大学工学部の楠田哲也教授を委員 長とし, 筆者らも委員として参加した公共下水道終末処 理場環境影響調査委員会が開催された. 本研究では, 杵築 市下水道課の許諾を得てこの委員会の成果の一部を活用 させていただいた. カブトガニ幼生の現地調査において は杵築市カブトガニ保護推進委員会のご協力を得た。 パ シフィックコンサルタンツ (株) 九州本社の徳田正史氏に 研究遂行上のご尽力をいただいた. また, 解析の一部は (財) 河川環境財団の河川整備基金による清野への研究支 援をもとに行われた.これらの方々に謝意を表します.

\section{参考文献}

1) Eric L. MILLS: Biological Oceanography -An Early History, 1870-1960, Cornell University Press, London, England, p. 378, 1989.

2) 中野 晋, 真子昌樹, 酒井勝司, 北野利一, 三井 宏: 河口 の環境指標生物「シオマネキ」の生態と水理・底質特性, 水 工学論文集, 第 41 巻, pp. 283-288, 1997.

3) 中野 晋, 藤井 勇, 真子昌樹, 北野利一, 三井宏: 浮遊 幼生期を持つ潮間帯動物「シオマネキ」と河口部の流れと の関係, 水工学論文集, 第 42 巻, pp. 1153-1158, 1998.

4) 清野聡子, 宇多高明, 真間修一, 三波俊郎, 芹沢真澄, 古池 鋼, 前田耕作, 日野明日香 : 絶㓕危惧生物カブトガニの生 息地として見た守江湾干渴の地形・波浪特性, 海岸工学論文 集, 第45巻, pp. 1096-1100, 1998.

5) 清野聡子, 前田耕作, 日野明日香, 宇多高明, 真間修一, 山 田伸雄 : カブトガニは何故その岸辺に産卵するのか? -産卵 場の地形・堆樍物・波・流れの特性一, 海岸工学論文集, 第 45 巻, pp. 1091-1095, 1998.

6) 清野伀子, 宇多高明, 大分県 : カブトガニの棲む干潟一八坂 川の河川改修と環境保全-,大分県, p. 57, 1999.

7) 前田耕作 : カブトガニTachypleus tridentatusの 1 齢幼生の 生態と産卵地の物理環境, 東京大学大学院総合文化研究科広 域システム科学科修士論文, p. 112, 1999.

8) 藤原正幸, 明田定満, 武内智行 : マルチレベル密度流モテル の開発と人工湧昇流への適用, 水工研技報, 14, pp. 13$35,1992$.

(1999. 9.30 受付) 